\title{
Neurosteroid Synthesis-Mediated Regulation of GABA Receptors: Relevance to the Ovarian Cycle and Stress
}

\author{
Jamie Maguire and Istvan Mody \\ Departments of Neurology and Physiology, The David Geffen School of Medicine, University of California, Los Angeles, Los Angeles, California 90095
}

Recently, we demonstrated cyclic alterations in $\mathrm{GABA}_{\mathrm{A}}$ receptor $\left(\mathrm{GABA}_{\mathrm{A}} \mathrm{R}\right)$ subunit composition over the ovarian cycle correlated with fluctuations in progesterone levels. However, it remains unclear whether this physiological regulation of $\mathrm{GABA}_{\mathrm{A}} \mathrm{Rs}$ is directly mediated by hormones. Here, we show that both ovarian and stress hormones are capable of reorganizing $\mathrm{GABA}_{\mathrm{A}} \mathrm{Rs}$ by actions through neurosteroid metabolites. The cyclic alterations in $\mathrm{GABA}_{\mathrm{A}} \mathrm{Rs}$ demonstrated in female mice can be mimicked with exogenous progesterone treatment in males or in ovariectomized females. Progesterone $\left(5 \mathrm{mg} / \mathrm{kg}\right.$, twice daily) upregulates the expression of $\mathrm{GABA}_{\mathrm{A}} \mathrm{R} \delta$ subunits and enhances the tonic inhibition mediated by these receptors in dentate gyrus granule cells (DGGCs). These changes in males as well as ovarian cycle-induced changes in females can be blocked by finasteride, an antagonist of neurosteroid synthesis from progesterone. The altered $\mathrm{GABA}_{\mathrm{A}} \mathrm{R}$ expression is unaffected by the progesterone receptor antagonist RU486 [mifepristone (11 $\beta$-[ $p$-(dimethylamino) phenyl]-17 $\beta$-hydroxy-17-(1-propynyl)estra-4,9-dien-3-one)], suggesting that neurosteroid synthesis and not progesterone receptor activation underlies the hormone-mediated effects on $\mathrm{GABA}_{\mathrm{A}} \mathrm{R}$ expression. Neurosteroids can alter $\mathrm{GABA}_{\mathrm{A}} \mathrm{R}$ expression on a rapid timescale, because $\mathrm{GABA}_{\mathrm{A}} \mathrm{R}$ upregulation can be induced in brain slices maintained in vitro after a short $(30 \mathrm{~min})$ treatment with the neurosteroid $3 \alpha, 5 \alpha$-tetrahydrodeoxycorticosterone (THDOC) (100 nM). Consistent with these rapid alterations, acute stress, a condition known to quickly raise THDOC levels, within 30 min induces upregulation of $\mathrm{GABA}_{\mathrm{A}} \mathrm{R} \delta$ subunit expression and increase tonic inhibition in DGGCs. These results reveal that several physiological conditions characterized by elevations in neurosteroid levels induce a reorganization of $\mathrm{GABA}_{\mathrm{A}} \mathrm{Rs}$ through the action of neurosteroids.

Key words: $\mathrm{GABA}_{\mathrm{A}} \mathrm{Rs}$; progesterone; neurosteroids; plasticity; stress; ovarian cycle

\section{Introduction}

During the ovarian cycle, when progesterone levels are elevated, $\mathrm{GABA}_{\mathrm{A}}$ receptors $\left(\mathrm{GABA}_{\mathrm{A}} \mathrm{Rs}\right)$ become reorganized to decrease neuronal excitability (Maguire et al., 2005). Similar ovarian cycle-related alterations in $\mathrm{GABA}_{\mathrm{A}} \mathrm{R}$ expression take place in the periaqueductal gray matter (Griffiths and Lovick, 2005b). The central question after observing any steroid hormone-related alterations in the CNS is whether the changes result from the direct activation of steroid hormone receptors (Li and O'Malley, 2003) or from the effects of the numerous steroid hormone metabolites, also referred to as neurosteroids, that are locally synthesized in the brain (Belelli and Lambert, 2005). The ability to regulate $\mathrm{GABA}_{\mathrm{A}} \mathrm{R}$ subunit composition would have tremendous therapeutic potential for a number of neurological disorders. Thus, we wanted to extend these studies to determine the mechanism of hormone-mediated $\mathrm{GABA}_{\mathrm{A}} \mathrm{R}$ regulation.

Steroid hormones, such as progesterone and corticosterone,

Received Nov. 14, 2006; revised Jan. 8, 2007; accepted Jan. 15, 2007.

This work was supported by National Institutes of Health Grants NS30549 and NS02808 and the Coelho Endowment (I.M.). J.M. was also supported by a fellowship from the Epilepsy Foundation of America. We thank Dr. W. Sieghart (University of Vienna, Vienna, Austria) for the generous gift of the $G A B A_{A} R \delta$ subunit antibody.

Correspondence should be addressed to Dr. Istvan Mody, Department of Neurology, Neuroscience Research Building 1, Room 575D, The David Geffen School of Medicine, University of California, Los Angeles, 635 Charles Young Drive South, Los Angeles, CA 90095. E-mail: mody@ucla.edu.

D01:10.1523/JNEUROSCI.4945-06.2007

Copyright $\odot 2007$ Society for Neuroscience $\quad$ 0270-6474/07/272155-08\$15.00/0 are known to exert a wide range of effects through both genomic mechanisms, primarily via activation of the nuclear hormone receptors, and nongenomic mechanisms, predominantly through action of neurosteroid metabolites on $\mathrm{GABA}_{\mathrm{A}} \mathrm{Rs}$ (for review, see Li and O'Malley, 2003). However, it remains unclear which of these mechanisms underlies changes in $\mathrm{GABA}_{\mathrm{A}} \mathrm{Rs}$ mediated by changes in steroid hormone levels.

Alterations in $\mathrm{GABA}_{\mathrm{A}} \mathrm{R}$ subunit composition are correlated with fluctuations in steroid hormone levels (Li and O'Malley, 2003), suggesting that ovarian cycle-linked changes in $\mathrm{GABA}_{\mathrm{A}} \mathrm{Rs}$ may occur at the level of gene transcription involving activation of steroid hormone receptors. In vitro studies suggest that progesterone is capable of regulating the expression of a number of $\mathrm{GABA}_{\mathrm{A}} \mathrm{R}$ genes (Pierson et al., 2005). Although the requirement of progesterone receptor activation in the regulation of $\mathrm{GABA}_{\mathrm{A}} \mathrm{R}$ gene expression has not been demonstrated (Pierson et al., 2005), the ability of progesterone to induce changes in $\mathrm{GABA}_{\mathrm{A}} \mathrm{R}$ gene expression in vitro, may take place in the absence of local neurosteroid synthesis.

Neurosteroids have been shown to alter $\mathrm{GABA}_{\mathrm{A}} \mathrm{R}$ subunit expression directly (Shen et al., 2005), which suggests that neurosteroid metabolites may be capable of regulating $\mathrm{GABA}_{\mathrm{A}} \mathrm{R}$ expression independent of the progesterone receptor. However, it is unclear how neurosteroid metabolites regulate the expression of $\mathrm{GABA}_{\mathrm{A}} \mathrm{R}$ subunits. Neurosteroids have been shown to regulate the activity of PKC (protein kinase C)-mediated phosphorylation 
of $\mathrm{GABA}_{\mathrm{A}}$ Rs (Brussaard and Koksma, 2003) and the surface expression of $\mathrm{GABA}_{\mathrm{A}}$ Rs depends on $\mathrm{GABA}_{\mathrm{A}} \mathrm{R}$ phosphorylation (for review, see Kittler and Moss, 2003), suggesting that neurosteroids themselves could regulate the surface expression of $G_{A B A} R$ subunits.

The goal of this study was to examine the mechanism of steroid hormone-mediated regulation of $\mathrm{GABA}_{\mathrm{A}}$ Rs. Gaining insight into the mechanisms of $\mathrm{GABA}_{\mathrm{A}} \mathrm{R}$ regulation would have tremendous therapeutic potential in the treatment of numerous neurological and psychiatric disorders. Here, we show that the steroid hormone-mediated regulation of $\mathrm{GABA}_{\mathrm{A}}$ Rs requires neurosteroid synthesis but not activation of steroid hormone receptors, revealing a direct regulatory action of neurosteroids on $\mathrm{GABA}_{\mathrm{A}}$ Rs.

\section{Materials and Methods}

Animal handling. We have taken steps to minimize the stress of the animals in each experimental group before anesthesia. Each animal was transferred to the dissection area in its home cage at least $2 \mathrm{~h}$ before anesthesia to acclimatize the animals to the new environment. To anesthetize the animals, the air around their home cage was gradually exchanged to a mixture of air plus a volatile anesthetic (halothane), thus avoiding any direct handling of unanesthetized animals. The $\mathrm{CO}_{2}$ exposure was performed in a manner similar to the volatile anesthetic administration. When the animal was fully anesthetized, it was removed from the home cage and rapidly decapitated. Maintaining the animals in their home cages and acclimatizing them before anesthesia substantially decreased the amount of stress the animals endure. All animals were handled identically, apart from the experimental manipulations.

Whole-cell recordings. Whole-cell patch-clamp recordings were performed on dentate gyrus granule cells (DGGCs) in 350- $\mu$ m-thick coronal hippocampal slices prepared from adult (3-4 months of age) C57BL/6 mice. The slices were perfused with normal artificial CSF (nACSF) (in mm: $126 \mathrm{NaCl}, 2.5 \mathrm{KCl}, 2 \mathrm{CaCl}_{2}, 1-2 \mathrm{MgCl}_{2}, 1.25 \mathrm{NaHPO}_{4}$, $26 \mathrm{NaHCO}_{3}$, and 10-25 [SCAP]D-glucose, bubbled with $95 \% \mathrm{O}_{2}$ and $5 \%$ $\left.\mathrm{CO}_{2}, \mathrm{pH} 7.3-7.4\right)$ containing 3-5 mM kynurenic acid and $5 \mu \mathrm{M}$ GABA (Sigma, St. Louis, MO) as described previously (Stell et al., 2003; Wei et al., 2004). Intracellular recording solution containing the following (in $\mathrm{mm}$ ): $140 \mathrm{CsCl}, 1 \mathrm{MgCl}_{2}, 10 \mathrm{HEPES}$, and $4 \mathrm{Na}-\mathrm{ATP}, \mathrm{pH}$ 7.25, 280-290 $\mathrm{mOsm}$, and electrodes with $\mathrm{DC}$ resistance of 2-5 $\mathrm{M} \Omega$ were used for all recordings. 2-(3-Carboxypropyl)-3-amino-6-(4-methoxyphenyl)pyridazinium bromide (SR95531) (>100 $\mu \mathrm{M}$ SR95531; Sigma) was added to the external recording solution where indicated. For the in vitro $3 \alpha, 5 \alpha-$ tetrahydrodeoxycorticosterone (THDOC) experiments, immediately after preparation, the slices were placed in ACSF containing $100 \mathrm{~nm}$ THDOC for $30 \mathrm{~min}$. After $30 \mathrm{~min}$ in THDOC, the slices were incubated in $\mathrm{nACSF}$ for $30 \mathrm{~min}$ up to $2 \mathrm{~h}$. Whole-cell patch-clamp recordings were then performed in slices at $30 \mathrm{~min}$ intervals. Data analysis was performed as described previously (Nusser and Mody, 2002; Stell and Mody, 2002; Stell et al., 2003). Briefly, the mean current was measured during $5 \mathrm{~ms}$ epochs collected every $100 \mathrm{~ms}$ throughout the experiment. A Gaussian fit to these points gave the mean current during a period of $10-30 \mathrm{~s}$ before the addition of SR95531 and after SR95531 addition. The difference between these two values was considered to be the tonic current. Statistical significance was determined using Student's $t$ test.

Western blot analysis. Western blot analysis was performed as described previously (Maguire et al., 2005). The hippocampus was rapidly dissected out from adult mice and homogenized in a buffer containing 50 $\mathrm{mm}$ Tris- $\mathrm{HCl}, 5 \mathrm{~mm}$ EDTA, $10 \mathrm{~mm}$ EGTA, and $0.5 \mathrm{~mm}$ dithiothreitol, in the presence of protease inhibitors (Complete Mini; Roche, Indianapolis, IN). The membrane fraction was isolated and protein concentrations were determined using the DC Protein Assay (Bio-Rad, Hercules, CA). A total of $100 \mu \mathrm{g}$ of total protein was subjected to SDS-PAGE and transferred to a nitrocellulose membrane (Amersham Biosciences, Piscataway, NJ), blocked in 10\% nonfat milk, and probed with a polyclonal antibody specific for the $\mathrm{GABA}_{\mathrm{A}} \mathrm{R} \delta$ (1:5000; a gift from Dr. W. Sieghart, University of Vienna, Vienna, Austria). The blots were incubated with peroxidase-labeled anti-rabbit IgG (1:2000; Vector Laboratories, Burlingame, CA), and immunoreactive proteins were visualized using enhanced chemiluminescence (Amersham Biosciences). Optical density measurements were determined using the NIH Image J software. Statistical significance was determined using ANOVA.

Acute stress paradigm. Adult male mice (3-4 months of age) remained in their home cage, the air around the home cage was then replaced for 2 min with a gas mixture containing $21 \% \mathrm{O}_{2}, 44 \% \mathrm{~N}_{2}$, and $35 \% \mathrm{CO}_{2}$. After $2 \mathrm{~min}$, the home cage was removed from the $\mathrm{CO}_{2}$ chamber, and the animals were allowed to recover for $30 \mathrm{~min}$ before experimentation.

Electrode implant and electroencephalogram recordings. Age-matched adult C57BL/6 mice (Harlan, Indianapolis, IN) were anesthetized with $100 \mathrm{mg} / \mathrm{kg}$ ketamine, $5.2 \mathrm{mg} / \mathrm{kg}$ xylazine, and $1.0 \mathrm{mg} / \mathrm{kg}$ acepromazine according to a protocol approved by the University of California, Los Angeles, Chancellor's Animal Research Committee. A lengthwise incision was made along the scalp, and a small burr hole was made $2.2 \mathrm{~mm}$ posterior to bregma and $1.7 \mathrm{~mm}$ lateral to the midline. A micromanipulator was used to place a hippocampal depth electrode (Plastics One, Roanoke, VA) in the hippocampus at a depth of $2.0 \mathrm{~mm}$. The electrode was fixed to the skull using dental cement, and the animal was allowed to recover for $48 \mathrm{~h}$ before recordings were undertaken. Electroencephalogram (EEG) recordings were started $10 \mathrm{~min}$ before an intraperitoneal injection of $15 \mathrm{mg} / \mathrm{kg}$ kainic acid (Sigma) and continued for $2 \mathrm{~h}$ after the injection. Recordings were low-pass filtered at $200 \mathrm{~Hz}$ and sampled at 1 $\mathrm{kHz}$ using an in-house Labview-based (National Instruments, Austin, TX) software. Seizure events were defined as changes in the amplitude of electrographic activity and identified by consistent changes in the power of the fast Fourier transform of the EEG. The "percentage time seizing" was calculated as the cumulative time of all seizure activity divided by 120 min (the duration of the recording period). Statistical analysis was done by ANOVA, setting a level of significance of $p<0.05$.

\section{Results}

Nuclear progesterone receptors are not involved in the control of GABARs, tonic inhibition, and neuronal excitability during the ovarian cycle

To determine whether progesterone acts via progesterone receptors or progesterone metabolites to mediate the changes in $\mathrm{GABA}_{\mathrm{A}} \mathrm{Rs}$ associated with the ovarian cycle, we analyzed changes in $\mathrm{GABA}_{\mathrm{A}} \mathrm{Rs}$ in female cycling mice treated with either the progesterone receptor antagonist, mifepristone $(11 \beta$ - $[p$-(dimethylamino)phenyl]-17 $\beta$-hydroxy-17-(1-propynyl)estra-4,9-dien-3one) (RU486) (50 mg/kg) (Borowicz et al., 2002; Xu et al., 1998), or the neurosteroid synthesis inhibitor, finasteride $(100 \mathrm{mg} / \mathrm{kg})$ (Kokate et al., 1999). Cycling females were treated with either RU486 or finasteride twice daily for $2 \mathrm{~d}$, beginning at estrus and continuing through diestrus. $\mathrm{GABA}_{\mathrm{A}} \mathrm{R}$ expression and function were then assessed, after $2 \mathrm{~d}$ of consecutive treatment, at late diestrus. Finasteride treatment prevents $\mathrm{GABA}_{\mathrm{A}} \mathrm{R} \delta$ subunit upregulation during diestrus (Fig. 1), suggesting that neurosteroid synthesis is required for $\mathrm{GABA}_{\mathrm{A}} \mathrm{R}$ regulation. The increase in $\mathrm{GABA}_{\mathrm{A}} \mathrm{R} \delta$ subunit expression observed during diestrus $(0.64 \pm$ $0.01 \mathrm{OD} / 100 \mu \mathrm{g}$ total protein) was blocked in mice treated with finasteride from estrus through diestrus $(0.53 \pm 0.01 \mathrm{OD} / 100 \mu \mathrm{g}$ total protein). The progesterone receptor antagonist, RU486, and the estrogen receptor antagonist, tamoxifen $(2 \mathrm{mg} / \mathrm{kg})$, had no significant effects on $\mathrm{GABA}_{\mathrm{A}} \mathrm{R} \delta$ subunit regulation over the ovarian cycle $(0.62 \pm 0.01$ and $0.62 \pm 0.02 \mathrm{OD} / 100 \mu \mathrm{g}$ total protein, respectively) (Fig. 1$)(n=4-7$ mice for each group; $p<$ $0.05)$. These results suggest that neurosteroid synthesis is required for regulating $\mathrm{GABA}_{\mathrm{A}} \mathrm{R}$ expression during the ovarian cycle. These data also demonstrate that progesterone receptor activation does not play a role in the ovarian cycle-dependent regulation of $\mathrm{GABA}_{\mathrm{A}}$ Rs. Furthermore, finasteride treatment from estrus through diestrus blocks the increase in $\mathrm{GABA}_{\mathrm{A}} \mathrm{R} \delta$ subunit-mediated tonic inhibition observed in DGGCs during 

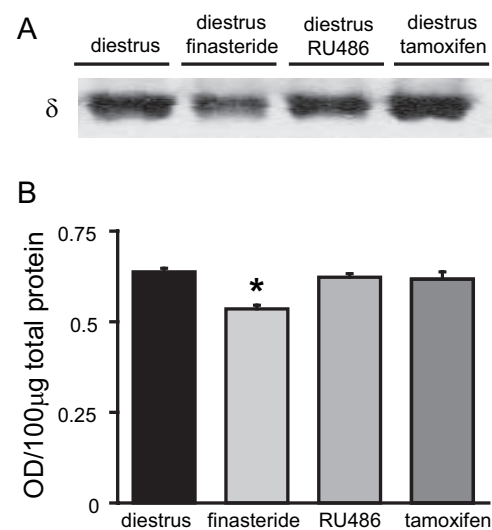

Figure 1. Neurosteroid synthesis is required for ovarian cycle-related changes in $G_{A B} A_{A} R s$. $A$, Representative immunoblots for $G A B A_{A} R \delta$ subunits of total membrane hippocampal protein from untreated diestrous mice or diestrous mice treated with either finasteride (100 mg/kg), RU486 $(50 \mathrm{mg} / \mathrm{kg})$, or tamoxifen $(1 \mathrm{mg} / \mathrm{kg})$ from estrus throughout diestrus. $\boldsymbol{B}$, The histogram of average optical density of Western blots highlights the blocking effect of finasteride, unlike RU486 or tamoxifen, on the upregulation of the $\mathrm{GABA}_{A} \mathrm{R} \delta$ subunit at diestrus. The asterisk denotes significance $(p<0.05)$. Error bars indicate SEM.
A

$\mathrm{B}$
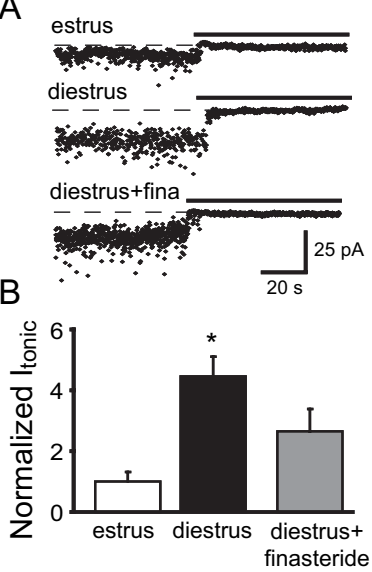

C
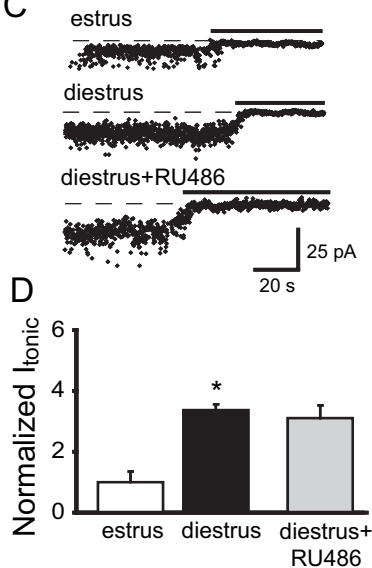

Figure 2. Neurosteroid synthesis is required to induce the increased tonic inhibition during diestrus. $A$, Representative recordings from control estrous and diestrous mice and mice treated with finasteride from estrus through diestrus. The dashed lines indicate the basal current in the presence of saturating concentrations of the $G_{A B A_{A} R}$ antagonist SR95531 that was perfused during the time indicated by the horizontal black bars. $\boldsymbol{B}$, The bar graphs of the average tonic current normalized to the average tonic current recorded during estrus in DGGCs show a significant increase in diestrous mice, which is blocked with finasteride treatment. The asterisk denotes significance ( $p<0.05, t$ test). $C$, Representative recordings from control estrous and diestrous mice and mice treated with RU486 from estrus through diestrus. D, Histogram of the average tonic current normalized to the average tonic current recorded during estrus in DGGCS demonstrates a significant increase in diestrous mice, which is unaffected by RU486 treatment. The asterisk denotes significance ( $p<0.05, t$ test). Error bars indicate SEM.

diestrus (Fig. 2). The increased GABAergic tonic inhibition in DGGCs during diestrus $(36.2 \pm 5.2 \mathrm{pA})$ compared with estrus $(8.1 \pm 2.6 \mathrm{pA})$ is significantly reduced by in vivo finasteride treatment $(16.0 \pm 2.8 \mathrm{pA})$ (Fig. 2$)(n=24$ cells; $n=9$ mice; $p<0.05)$. RU486 treatment of the animals at diestrus $(20.6 \pm 2.8 \mathrm{pA})$ had no significant effect on the tonic current measured in DGGCs compared with untreated controls $(22.3 \pm 1.3 \mathrm{pA})$ (Fig. 2$)(n=$ 21 cells; $n=8$ mice; $p>0.05)$, which is still significantly larger than untreated estrous mice ( $6.6 \pm 2.3 \mathrm{pA})$ (Fig. 2$)(n=21$ cells; $n=8$ mice; $p<0.05$ ).

To determine the effects of blocking neurosteroid synthesis on neuronal excitability, female mice were treated for 2 consecutive
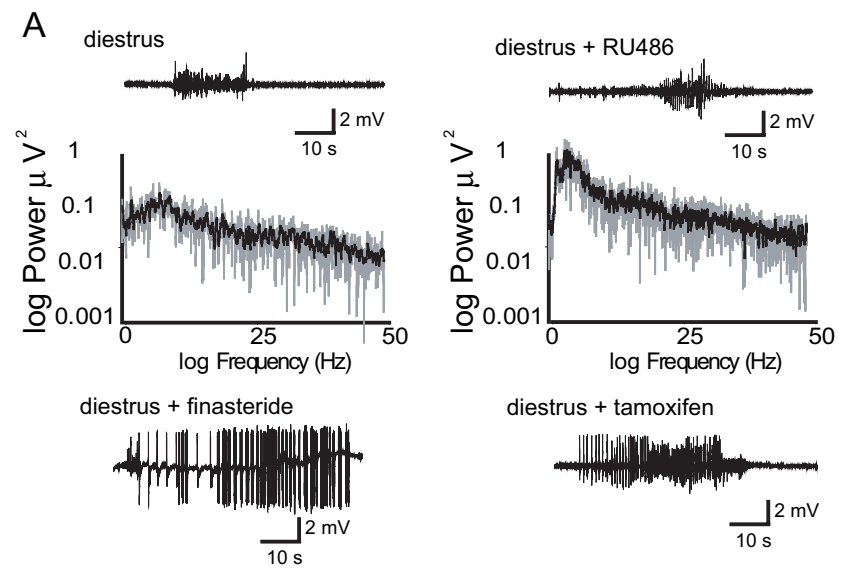

diestrus + tamoxifen
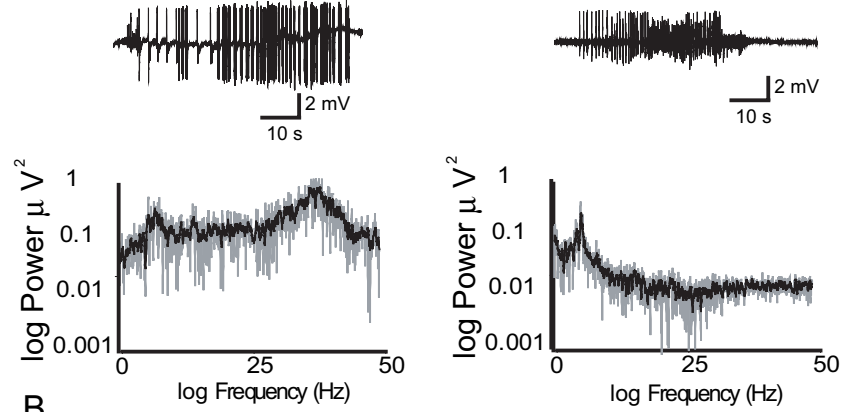

$\mathrm{B}$

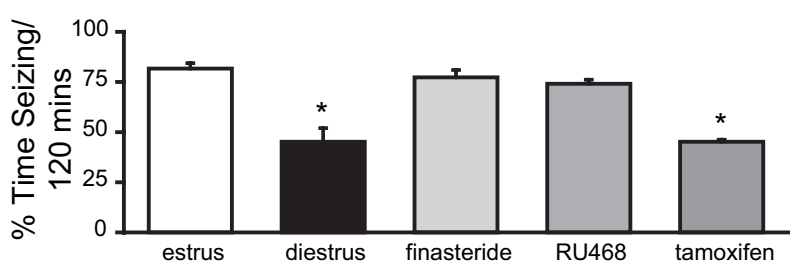

Figure 3. The decrease in excitability during diestrus is mediated by neurosteroid synthesis. $\boldsymbol{A}$, Representative EEG recordings from control diestrous mice and diestrous mice treated with RU486, finasteride, or tamoxifen. Finasteride blocks the decrease in excitability during diestrus. Fast Fourier transform analysis demonstrates the increased power of the EEG in diestrous mice treated with finasteride. $\boldsymbol{B}$, The histograms of the percentage time seizing per $2 \mathrm{~h}$ recording session show the decrease in seizure activity during diestrus, which is blocked by finasteride treatment. The asterisk denotes significance $(p<0.05)$. Error bars indicate SEM.

days, beginning at estrus through diestrus with either finasteride, RU486, or tamoxifen. After $2 \mathrm{~d}$ of treatment, seizure susceptibility in response to $15 \mathrm{mg} / \mathrm{kg}$ kainic acid was analyzed at diestrus by hippocampal depth electrode EEG recordings. Diestrous mice exhibit a decrease in the cumulative percentage time seizing in the $2 \mathrm{~h}$ after kainic acid administration $(45.2 \pm 6.8 \%)$ compared with estrous mice $(81.7 \pm 2.7 \%)$ (Fig. 3 ), which is blocked with finasteride $(77.3 \pm 3.7 \%)$ and RU486 $(74.1 \pm 2.0 \%)$ but is unaffected by tamoxifen (45.2 $\pm 1.0 \%)$ (Fig. 3$)(n=4-7$ mice for each group; $p<0.05$ ). The effect of RU486 on seizure susceptibility was surprising in light of the lack of RU486 effect on $G_{A B A} R$ subunit expression and tonic inhibition. These pharmacological results are consistent with the idea that neurosteroid synthesis is required for the ovarian cycle-linked changes in neuronal excitability.

Changes observed during the ovarian cycle can be mimicked by progesterone administration to males and ovariectomized females

Additional evidence that the changes in $\mathrm{GABA}_{\mathrm{A}} \mathrm{Rs}$ are mediated by progesterone metabolites comes from the evidence that the changes in $\mathrm{GABA}_{\mathrm{A}} \mathrm{Rs}$ observed over the ovarian cycle of female mice can be mimicked in male mice and ovariectomized females treated with progesterone. Male mice were treated with $5 \mathrm{mg} / \mathrm{kg}$ twice daily for $2 \mathrm{~d}$, which results in plasma levels of progesterone 
A

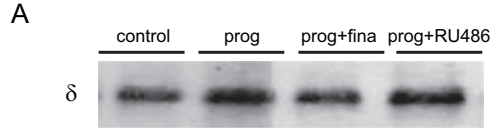

B

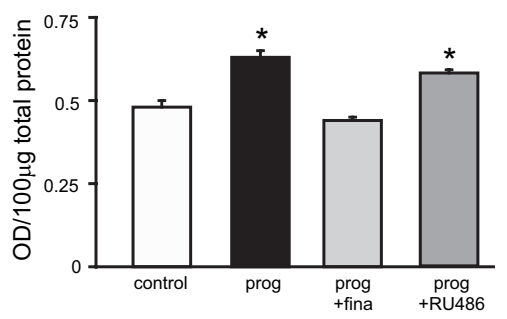

Figure 4. Progesterone mediates the changes in $\mathrm{GABA}_{\mathrm{A}} \mathrm{Rs}$ related to the ovarian cycle. $\boldsymbol{A}$, Representative immunoblots of total membrane hippocampal protein from untreated male mice or male mice treated with $5 \mathrm{mg} / \mathrm{kg}$ progesterone twice daily for $2 \mathrm{~d}$ alone or in combination with either finasteride or RU486. B, The histogram of average optical density of Western blots demonstrates that progesterone administration increases $G A B A_{A} R \delta$ subunit expression, which can be blocked with finasteride treatment but not with RU486. The asterisk denotes significance $(p<0.05)$. Error bars indicate SEM. prog, Progesterone; fina, finasteride.

analogous to that of diestrous females (data not shown), induced an increase in $\mathrm{GABA}_{\mathrm{A}} \mathrm{R} \delta$ subunit expression $(0.63 \pm 0.02 \mathrm{OD} /$ $100 \mu \mathrm{g}$ total protein) compared with untreated controls $(0.49 \pm$ $0.02 \mathrm{OD} / 100 \mu \mathrm{g}$ total protein) (Fig. 4) $(n=4-8$ mice for each group; $p<0.05)$. Consistent with an upregulation of $\mathrm{GABA}_{\mathrm{A}} \mathrm{R} \delta$ subunit expression, progesterone administration to ovariectomized females increases the tonic GABAergic inhibition in DGGCs $(70.1 \pm 10.01 \mathrm{pA})$ compared with untreated ovariectomized controls (23.0 $\pm 5.32 \mathrm{pA})$ (Fig. 4$)(n=3$ mice for each group; $p<$ $0.05)$. Similar to the regulation of $\mathrm{GABA}_{\mathrm{A}} \mathrm{Rs}$ in cycling female mice, the increase in $\mathrm{GABA}_{\mathrm{A}} \mathrm{R} \delta$ subunit expression by progesterone $(0.63 \pm 0.02 \mathrm{OD} / 100 \mu \mathrm{g}$ total protein) compared with untreated males $(0.49 \pm 0.02 \mathrm{OD} / 100 \mu \mathrm{g}$ total protein) was blocked by finasteride $(100 \mathrm{mg} / \mathrm{kg})(0.44 \pm 0.01 \mathrm{OD} / 100 \mu \mathrm{g}$ total protein $)$ (Fig. 4) ( $n=4-8$ mice for each group; $p<0.05)$, but not by RU486 treatment $(50 \mathrm{mg} / \mathrm{kg})(0.58 \pm 0.01 \mathrm{OD} / 100 \mu \mathrm{g}$ total protein) (Fig. 4) $(n=4-8$ mice for each group; $p>0.05)$. These results further demonstrate the requirement of neurosteroid synthesis in mediating the regulation of $\mathrm{GABA}_{\mathrm{A}} \mathrm{Rs}$ by progesterone.

Males treated with progesterone exhibit a decrease in the cumulative percentage time seizing per $2 \mathrm{~h}$ after kainic acid administration $(32.1 \pm 2.9 \%)$ compared with untreated males (66.3 \pm $8.9 \%)$ (Fig. 5) ( $n=4-6$ mice for each group; $p<0.05)$. This anticonvulsant action of progesterone in males is also blocked by treatment with finasteride $(79.3 \pm 6.6 \%)$, but is unaltered by administration of RU486 (27.3 $\pm 6.1 \%)$ (Fig. 5) ( $n=4-8$ mice for each group), further suggesting that the effects of progesterone on $\mathrm{GABA}_{\mathrm{A}} \mathrm{R}$ regulation and excitability are mediated by neurosteroid metabolites of progesterone.

\section{Rapid changes in $\mathrm{GABA}_{\mathrm{A}} \mathrm{R}$ expression and function induced by stress hormones}

We have demonstrated that there are ovarian hormone-mediated changes in $\mathrm{GABA}_{\mathrm{A}} \mathrm{R}$ expression and function mediated by neurosteroid metabolites. To determine whether changes in $\mathrm{GABA}_{\mathrm{A}}$ Rs are unique to conditions of elevated ovarian hormone levels, we analyzed the changes in $\mathrm{GABA}_{\mathrm{A}}$ Rs associated with elevations in stress hormones after a single acute stressful episode. Mice were acutely stressed ( $2 \mathrm{~min}$ of $\mathrm{CO}_{2}$ exposure) (Barbaccia et
A
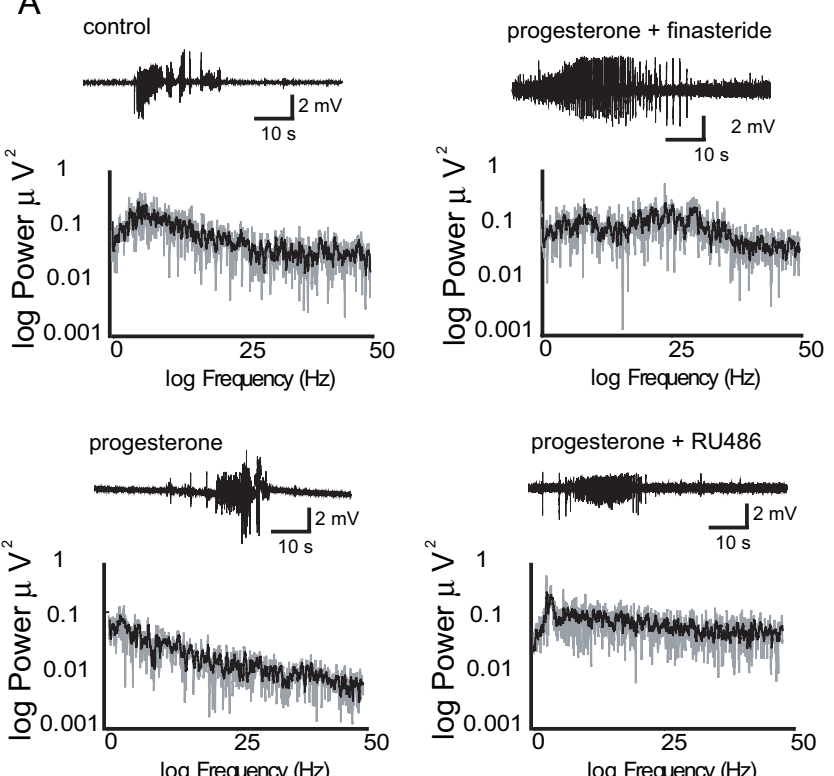

B

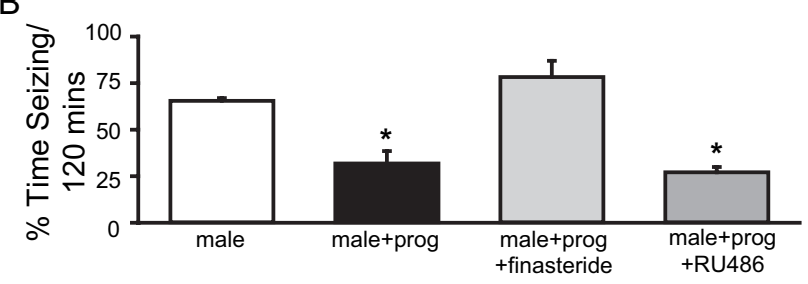

Figure 5. Neurosteroid synthesis from exogenous progesterone administration decreased excitability. $\boldsymbol{A}$, Representative EEG recordings from control male mice and male mice treated twice daily for $2 \mathrm{~d}$ with $5 \mathrm{mg} / \mathrm{kg}$ progesterone alone or in combination with finasteride or RU486. Finasteride blocks the decrease in excitability in progesterone-treated males. Fast Fourier transform analysis demonstrates the increase in power in diestrous mice treated with finasteride. $\boldsymbol{B}$, The histograms of the percentage time seizing per $2 \mathrm{~h}$ recording session demonstrate the decrease in excitability in progesterone-treated males, which is blocked only by finasteride not by RU486. The asterisk denotes significance $(p<0.05)$. Error bars indicate SEM. prog, Progesterone.

al., 1994), and $\mathrm{GABA}_{\mathrm{A}} \mathrm{R}$ expression was analyzed by Western blot in brain tissue prepared $30 \mathrm{~min}$ after the acute stress episode. Acute stress causes an increase in $\mathrm{GABA}_{\mathrm{A}} \mathrm{R} \delta$ subunit expression compared with controls (Fig. $6 A, C$ ). $\mathrm{GABA}_{\mathrm{A}} \mathrm{R} \delta$ subunit expression is increased after $\mathrm{CO}_{2}$ stress $(1.15 \pm 0.02 \mathrm{OD} / 100 \mu \mathrm{g}$ total protein) compared with unstressed control mice $(0.31 \pm 0.02$ $\mathrm{OD} / 100 \mu \mathrm{g}$ total protein) (Fig. $6 C)(n=4$ mice for each group; $p<0.05)$. Consistent with an increase in $\mathrm{GABA}_{\mathrm{A}} \mathrm{R} \delta$ subunit expression, we also find an increase in tonic inhibition mediated by these receptors in DGGCs of mice exposed to the acute $\mathrm{CO}_{2}$ stress episode compared with controls (Fig. 6B,D). Tonic inhibition is increased in DGGCs in mice exposed to $2 \mathrm{~min}$ of $\mathrm{CO}_{2}$ stress $(50.2 \pm 7.6 \mathrm{pA})$ compared with controls $(22.4 \pm 3.9 \mathrm{pA})$ (Fig. $6 B, D)(n=26$ cells; $n=8$ mice; $p<0.05)$. There is no significant difference in the frequency, peak amplitude, or decay time of spontaneous IPSCs (sIPSCs) in mice exposed to $\mathrm{CO}_{2}$ $(1.7 \pm 0.4 \mathrm{~Hz} ; 43.7 \pm 4.3 \mathrm{pA} ; 11.8 \pm 0.9 \mathrm{~ms})$ compared with controls $(1.3 \pm 0.3 \mathrm{~Hz} ; 46.4 \pm 2.7 \mathrm{pA} ; 15.3 \pm 0.7 \mathrm{~ms}$ ) (Fig. $6 D$ ) $(n=26$ cells; $n=8$ mice; $p>0.05)$. These results demonstrate alterations in $\mathrm{GABA}_{\mathrm{A}} \mathrm{R}$ structure and function after acute stress attributable to elevations in neurosteroid levels. 
A

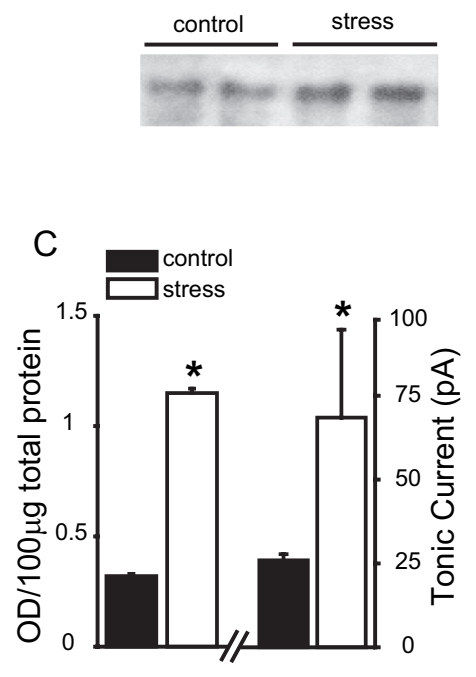

B

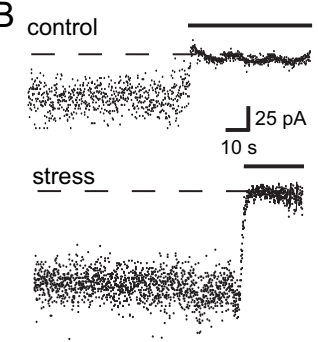

D

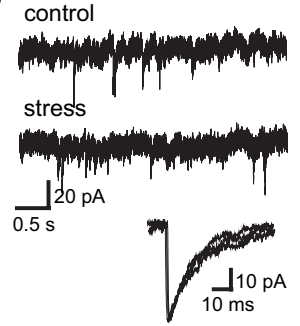

Figure 6. Acute stress increases $G A B A_{A} R \delta$ subunit expression and tonic inhibition. $\boldsymbol{A}$, Representative immunoblots with antibodies to $G_{A B A} R \delta$ subunits of total membrane hippocampal protein from two unstressed control male mice and two mice male mice exposed to 2 min of $\mathrm{CO}_{2}$ stress. $\boldsymbol{B}$, Representative recordings from control unstressed male mice and male mice subjected to 2 min of $\mathrm{CO}_{2}$ stress. $C$, The bar graphs of average optical densities of Western blots and average tonic current demonstrate the upregulation of the $G A B A_{A} R \delta$ subunit expression and increased tonic inhibition after acute stress compared with control. The asterisk denotes significance $(p<0.05)$. Error bars indicate SEM. $\boldsymbol{D}$, Representative recordings from control unstressed males and males exposed to $2 \mathrm{~min}$ of $\mathrm{CO}_{2}$ stress. The inset shows superimposed averaged sIPSCs recorded in DGGCS from control unstressed and males exposed to $2 \mathrm{~min}$ of $\mathrm{CO}_{2}$ stress.

Lasting changes in tonic inhibition after a transient acute treatment with the stress-related neurosteroid derivative THDOC

To determine whether the changes in $\mathrm{GABA}_{\mathrm{A}} \mathrm{R}$ structure and function after stress are attributable to the action of neurosteroid metabolites, we analyzed the effect of a transient exposure of brain slices to $100 \mathrm{~nm}$ THDOC on GABAergic inhibition in vitro. Whole-cell patch-clamp recording performed on acute hippocampal slices exposed to THDOC (30 min) exhibited a significant increase in tonic inhibition in DGGCs at all times up to $2 \mathrm{~h}$ after THDOC washout (Fig. 7). The tonic inhibition in DGGCs was increased after THDOC treatment at $30 \mathrm{~min}$ of nACSF washout $(103.1 \pm 27.2 \mathrm{pA}), 1 \mathrm{~h}(151.0 \pm 26.2 \mathrm{pA}), 1.5 \mathrm{~h}(106.6 \pm 20.1$ $\mathrm{pA})$, and $2 \mathrm{~h}(126.5 \pm 54.8 \mathrm{pA})$ compared with untreated slices $(22.4 \pm 3.9$ pA) (Fig. 7$)(n=28$ cells; $n=10$ mice; $p<0.05)$. These results suggest that the changes in $\mathrm{GABA}_{\mathrm{A}} \mathrm{Rs}$ (i.e., the increase in $\mathrm{GABA}_{\mathrm{A}} \mathrm{R} \delta$ subunit expression) induced by neurosteroid exposure are maintained for at least $2 \mathrm{~h}$ after washout with nACSF. There are no changes in the frequency ( $2.2 \pm 0.4$ vs $1.5 \pm$ $0.4 \mathrm{~Hz})$, peak amplitude $(45.4 \pm 3.9$ vs $46.5 \pm 2.7 \mathrm{pA})$, or decay time (15.2 \pm 1.3 vs $15.4 \pm 0.7 \mathrm{~ms})$ of the spontaneous IPSCs at any time after THDOC treatment compared with control untreated slices (Fig. 7) $(n=28$ cells; $n=10$ mice; $p>0.05)$.

To evaluate the washout of THDOC from slices, we performed whole-cell patch-clamp recordings on dentate DGGCs and perfused $100 \mathrm{~nm}$ THDOC onto the slices for $5 \mathrm{~min}$ followed by a wash with normal ACSF for $15 \mathrm{~min}$. The sIPSC properties were measured before the addition of THDOC, during perfusion of THDOC, and 15 min after the washout of THDOC from the slices. A 15 min THDOC washout was sufficient to remove the effect of THDOC on sIPSCs (average \pm SEM amplitude, before,

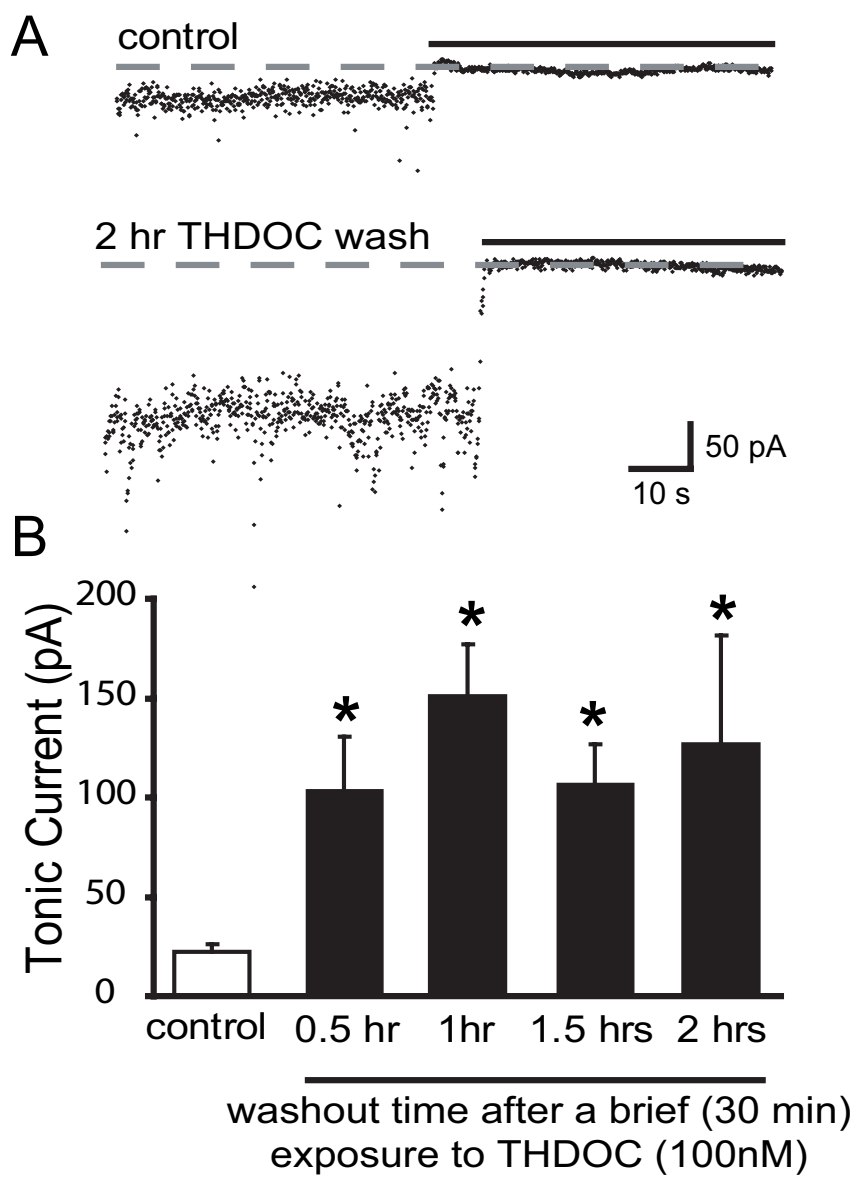

Figure 7. Acute THDOC treatment in vitro induces a long-lasting increase in tonic inhibition. A, Representative recordings in DGGCs from control slices and slices treated for 30 min with THDOC, and then washed out for $2 \mathrm{~h}$. Note the increase in tonic current in slices treated with THDOC despite the $2 \mathrm{~h}$ washout, suggesting long-lasting changes in tonic inhibition. $B, B a r$ graphs show the average tonic current in DGGCs from control slices or slices acutely treated with THDOC after increasing periods of washout. Acute THDOC treatment significantly enhances tonic current after various lengths of washout from $30 \mathrm{~min}$ to $2 \mathrm{~h}$. The asterisk denotes significance ( $p<0.05, t$ test). Error bars indicate SEM.

$42.7 \pm 6.5 \mathrm{pA}$; during, $61.6 \pm 7.9 \mathrm{pA}$; after, $32.0 \pm 16.0 \mathrm{pA}$; average \pm SEM decay time constant, before, $15.8 \pm 0.9 \mathrm{~ms}$; during, $20.2 \pm 1.0 \mathrm{~ms}$; after, $17.3 \pm 1.0 \mathrm{~ms} ; n=10$ ). These findings demonstrate that allowing for $30-120 \mathrm{~min}$ of THDOC washout is sufficient to remove THDOC from the slice, and thus the changes we observe in tonic inhibition must be attributable to rapid changes in $\mathrm{GABA}_{\mathrm{A}} \mathrm{Rs}$ rather than an incomplete washout of the neurosteroid from the slices.

\section{Discussion}

In the present study, we demonstrate that neurosteroid metabolites are capable of regulating the expression, and thereby function, of $\mathrm{GABA}_{\mathrm{A}} \mathrm{Rs}$. Here, we show that a condition that is characterized by elevated levels of neurosteroids induces altered expression of $\mathrm{GABA}_{\mathrm{A}} \mathrm{Rs}$, such that the $\delta$ subunit, which is mainly responsible for neurosteroid modulation, is upregulated and the tonic inhibition mediated by these receptors is enhanced, thus decreasing neuronal excitability. Regulation of $\mathrm{GABA}_{\mathrm{A}}$ Rs by hormones has been presumed to be either direct allosteric modulation of $\mathrm{GABA}_{\mathrm{A}} \mathrm{Rs}$ by neurosteroid metabolites or longer-term structural changes mediated by hormone receptor activation. Our results indicate that neurosteroids themselves are capable of 
inducing alterations in $\mathrm{GABA}_{\mathrm{A}} \mathrm{Rs}$ and may mediate changes in neuronal excitability associated with conditions of elevated neurosteroid levels (i.e., stress). These results provide new insight into the possible mechanisms responsible for regulation of $\mathrm{GABA}_{\mathrm{A}} \mathrm{Rs}$.

\section{Neurosteroid regulation of $\mathrm{GABA}_{\mathrm{A}} \mathrm{Rs}$}

Steroid hormones, both progesterone and estrogen, have been shown to play a role in synaptic plasticity in many different brain regions of several species (Terasawa and Timiras, 1968; Kawakami et al., 1969; Teyler et al., 1980; Gould et al., 1990; Woolley and McEwen, 1992). However, only one study has addressed the mechanism of steroid hormone-mediated synaptic plasticity. Alterations in spine density over the ovarian cycle are mediated by progesterone receptor activation (Woolley and McEwen, 1993) but also require activation of NMDA receptors (Woolley and McEwen, 1994), suggesting that activation of neurotransmitter receptors may be involved in the regulation of neuronal function by steroids.

Based on our findings, neurosteroid metabolites, presumably acting at $\delta$ subunit-containing $\mathrm{GABA}_{\mathrm{A}} \mathrm{Rs}$, are also required for steroid hormone-mediated regulation of $\mathrm{GABA}_{\mathrm{A}}$ Rs. Neurosteroids are known to be potent allosteric modulators of $\mathrm{GABA}_{\mathrm{A}} \mathrm{Rs}$, but how is it that neurosteroids may alter $\mathrm{GABA}_{\mathrm{A}} \mathrm{R}$ levels on the surface of nerve cells? Previous studies have shown that exogenous neurosteroid administration alters $\mathrm{GABA}_{\mathrm{A}} \mathrm{R}$ subunit expression (Shen et al., 2005), suggesting that these metabolites of steroid hormones can regulate $\mathrm{GABA}_{\mathrm{A}}$ Rs. Blocking neurosteroid synthesis, using finasteride, prevents changes in $\mathrm{GABA}_{\mathrm{A}} \mathrm{R}$ mRNA levels observed during pregnancy (Concas et al., 1998 ), suggesting that alterations in $\mathrm{GABA}_{\mathrm{A}}$ Rs are not a consequence of progesterone acting on progesterone receptors but rather of neurosteroid action at the steroid recognition site on $\mathrm{GABA}_{\mathrm{A}}$ receptors (Weiland and Orchinik, 1995; Concas et al., 1998). Neurosteroid-mediated changes in $\mathrm{GABA}_{\mathrm{A}}$ receptor subunit expression are not limited to progesterone-derived neurosteroids, such as allopregnanolone. Corticosterone induces complex changes in $\mathrm{GABA}_{\mathrm{A}}$ receptor pharmacology (Orchinik et al., 1995). Our data support the hypothesis that neurosteroid metabolites may directly alter $\mathrm{GABA}_{\mathrm{A}}$ receptor subunit expression in the neuronal membrane independent of steroid hormone receptor activation.

The fact that steroid hormone-associated alterations in $\mathrm{GABA}_{\mathrm{A}}$ Rs are mediated by neurosteroid metabolites and not by activation of steroid hormone receptors is further suggested from the similar regulation in $\mathrm{GABA}_{\mathrm{A}}$ Rs between males and females. There is no evidence for any gender differences in the distribution of $\mathrm{GABA}_{\mathrm{A}}$ Rs or hormone receptors (Lauber et al., 1991; Simerly and Young, 1991); thus, if $\mathrm{GABA}_{\mathrm{A}} \mathrm{R}$ subunit regulation is mediated by neurosteroids, gender differences should not affect $\mathrm{GABA}_{\mathrm{A}} \mathrm{R}$ regulation. Consistent with the lack of gender differences in neurosteroid regulation of $\mathrm{GABA}_{\mathrm{A}} \mathrm{Rs}$, there are no gender differences in their neurosteroid sensitivity in a variety of brain regions (Wilson and Biscardi, 1997).

It remains unclear how neurosteroid metabolites, acting independently of steroid hormone receptors, are able to induce changes in $\mathrm{GABA}_{\mathrm{A}}$ receptor subunit expression. Neurosteroids are synthesized in hippocampal principal neurons, not interneurons (Agis-Balboa et al., 2006), by the enzymatic metabolism of steroid precursors. These neurosteroids can then act in either a paracrine or autocrine manner on $\mathrm{GABA}_{\mathrm{A}}$ Rs to regulate excitability. Release of neurosteroids specifically by principal glutamatergic neurons in the hippocampus (Agis-Balboa et al., 2006), including DGGCs, suggests that the neurosteroid-mediated changes in $\mathrm{GABA}_{\mathrm{A}}$ Rs may be attributable to local neurosteroid synthesis and release from principal neurons acting on themselves or on other nearby cells. The GABA $\mathrm{R} \delta$ subunit is mainly localized in the DGGC dendrites (Wei et al., 2003) and has similarities to those proteins known to undergo dendritic targeting and local translation (Steward and Schuman, 2001). Therefore, its function may be regulated by dendritic mRNA synthesis. The expression of $\mathrm{GABA}_{\mathrm{A}} \mathrm{Rs}$ has been shown to be modulated by $\mathrm{GABA}_{\mathrm{A}} \mathrm{R}$ phosphorylation (for review, see Kittler and Moss, 2003). The impact of phosphorylation on $\mathrm{GABA}_{\mathrm{A}} \mathrm{R}$ activity has been described primarily for $\mathrm{GABA}_{\mathrm{A}} \mathrm{R}$ subunits mediating the phasic component of GABAergic inhibition (Essrich et al., 1998; Brandon et al., 2000, 2001) (for review, see Kittler and Moss, 2003). However, the role of phosphorylation in the regulation of extrasynaptic $\mathrm{GABA}_{\mathrm{A}} \mathrm{Rs}$ is not clear, but phosphorylation can alter the neurosteroid sensitivity of $\mathrm{GABA}_{\mathrm{A}}$ Rs at synapses (Brussaard et al., 2000; Fancsik et al., 2000; Hodge et al., 2002; Harney et al., 2003). Another potential mechanism for the neurosteroiddependent increase in $\mathrm{GABA}_{\mathrm{A}} \mathrm{R}$ expression is to interfere with the dynamin-dependent endocytosis of the receptors (Bogdanov et al., 2006).

\section{RU486 and excitability}

We have observed gender differences in the effect of RU486 on neuronal excitability. RU486 did not have a significant effect on neuronal excitability in males but increased excitability in cycling females. These data suggest that antagonists at progesterone receptors have different effects in male versus female animals. However, we do not see a difference in the effect of RU486 on the regulation of $\mathrm{GABA}_{\mathrm{A}} \mathrm{Rs}$, suggesting that perhaps the gender differences in excitability are attributable to other effects of RU486 not directly related to blocking progesterone receptor activation. An indirect role of RU486 in the observed gender differences on seizure susceptibility is supported by the reported lack of differences in progesterone receptor expression in the CNS of male and female mice. The reason for the increased excitability induced by RU486 in females remains to be determined, but may be attributable to its potential effect of increasing estrogen levels shown in pregnant females treated with RU486 (Fang et al., 1997). Estrogen is known to increase excitability in response to kainic acid administration (Woolley, 2000). A proconvulsant effect of elevated estrogen in females treated with RU486 may underlie the observed differences in seizure susceptibility between males and females treated with RU486. Nevertheless, according to our findings, blocking the progesterone receptor with RU486 does not have an effect on the steroid hormone regulation of $\mathrm{GABA}_{\mathrm{A}} \mathrm{Rs}$.

\section{Stress}

Stress is known to cause elevations in neurosteroid levels, in particular a derivative of corticosterone, the neurosteroid THDOC (Purdy et al., 1991; Barbaccia et al., 1996b, 2001; McEwen, 2002; Reddy and Rogawski, 2002), as well as allopregnanolone (Barbaccia et al., 1996a) (for review, see Reddy, 2003). Several studies, relying heavily on binding and uptake assays, have demonstrated changes in $\mathrm{GABA}_{\mathrm{A}} \mathrm{R}$ function after stress (Skerritt et al., 1981; Schwartz et al., 1987; Akinci and Johnston, 1993; Serra et al., 2000). However, the impact of increased stress-related neurosteroid levels on the expression of specific $\mathrm{GABA}_{\mathrm{A}} \mathrm{Rs}$ was previously unknown. The correlation between elevated levels of neurosteroids over the ovarian cycle and altered expression of $\mathrm{GABA}_{\mathrm{A}} \mathrm{R}$ subunits, specifically upregulation of $\mathrm{GABA}_{\mathrm{A}} \mathrm{R} \delta$ subunit expression (Griffiths and Lovick, 2005a; Maguire et al., 2005), appears 
to be analogous with the effect of elevated neurosteroid levels after stress (Fig. 6A, C).

Acute versus chronic stress have opposite effects on GABAergic function. Acute stress increases $\mathrm{GABA}_{\mathrm{A}} \mathrm{R}$-mediated chloride influx (Schwartz et al., 1987), whereas a decrease in GABAergic function is associated with chronic stress (Serra et al., 2000). In addition, the effects of neurosteroids on $\mathrm{GABA}_{\mathrm{A}} \mathrm{R}$ subunit expression also appear to have a bimodal effect, such that shortterm exposure as well as withdrawal from neurosteroids appear to exert similar effects (Sundstrom-Poromaa et al., 2002). This bimodal action of neurosteroids on $\mathrm{GABA}_{\mathrm{A}}$ Rs may underlie the profound differences in acute versus chronic stress on neuronal excitability. Chronic stress is a well known seizure trigger (Frucht et al., 2000; Chadda and Devaud, 2004); however, counterintuitive to the proconvulsant effect of chronic stress, acute stress has been shown to be anticonvulsant (Reddy and Rogawski, 2002). Acute stress enhances the binding of GABA agonists (Skerritt et al., 1981; Akinci and Johnston, 1993) and decreases seizure susceptibility (Pericic et al., 2001), which is correlated with elevated neurosteroid levels (Reddy, 2003). However, until now, additional analysis of the role of specific $\mathrm{GABA}_{\mathrm{A}} \mathrm{R}$ subunits in the stress-associated decreased seizure susceptibility was not available.

We have shown that elevations in neurosteroid levels associated with an acute stressful episode induce alterations in $\mathrm{GABA}_{\mathrm{A}} \mathrm{Rs}$, which may function to maintain the balance between excitation and inhibition after stress. The duration of neurosteroid exposure and the rate of decline of neurosteroid levels may be critical for the regulation of $\mathrm{GABA}_{\mathrm{A}}$ Rs. The key to the regulation may be a relatively rapid rise and fall in neurosteroid levels, because long-term exposure to positive allosteric modulators such as benzodiazepines, alcohol, and even neurosteroids result in a downregulation of receptor function (Bateson, 2002; Krystal et al., 2006; Reddy, 2006). Disruption in the regulation of $\mathrm{GABA}_{\mathrm{A}} \mathrm{Rs}$ in response to stress may underlie the stress-induced exacerbation of many psychiatric and neurological disorders. The upregulation of $\mathrm{GABA}_{\mathrm{A}} \mathrm{R} \delta$ subunit expression after an acute stressful episode may be a protective mechanism to prevent an imbalance in neuronal excitability. Our results demonstrate that, in addition to the direct allosteric modulation of $\mathrm{GABA}_{\mathrm{A}} \mathrm{Rs}$, neurosteroids also regulate $\mathrm{GABA}_{\mathrm{A}} \mathrm{Rs}$ on a longer timescale by altering the expression of specific $\mathrm{GABA}_{\mathrm{A}} \mathrm{R}$ subunits. This may have implications on the clinical use of neurosteroid synthesis inhibitors such as finasteride (Propecia), because certain neurological disorders related to steroid hormone changes may be worsened by finasteride treatment (Herzog and Frye, 2003).

\section{References}

Agis-Balboa RC, Pinna G, Zhubi A, Maloku E, Veldic M, Costa E, Guidotti A (2006) Characterization of brain neurons that express enzymes mediating neurosteroid biosynthesis. Proc Natl Acad Sci USA 103:14602-14607.

Akinci MK, Johnston GA (1993) Sex differences in acute swim stressinduced changes in the binding of MK-801 to the NMDA subclass of glutamate receptors in mouse forebrain. J Neurochem 61:2290-2293.

Barbaccia ML, Roscetti G, Trabucchi M, Cuccheddu T, Concas A, Biggio G (1994) Neurosteroids in the brain of handling-habituated and naive rats: effect of $\mathrm{CO}_{2}$ inhalation. Eur J Pharmacol 261:317-320.

Barbaccia ML, Roscetti G, Trabucchi M, Mostallino MC, Concas A, Purdy RH, Biggio G (1996a) Time-dependent changes in rat brain neuroactive steroid concentrations and $\mathrm{GABA}(\mathrm{A})$ receptor function after acute stress. Neuroendocrinology 63:166-172.

Barbaccia ML, Concas A, Roscetti G, Bolacchi F, Mostallino MC, Purdy RH, Biggio G (1996b) Stress-induced increase in brain neuroactive steroids: antagonism by abecarnil. Pharmacol Biochem Behav 54:205-210.
Barbaccia ML, Serra M, Purdy RH, Biggio G (2001) Stress and neuroactive steroids. Neurosteroids Brain Funct 46:243-272.

Bateson AN (2002) Basic pharmacologic mechanisms involved in benzodiazepine tolerance and withdrawal. Curr Pharm Des 8:5-21.

Belelli D, Lambert JJ (2005) Neurosteroids: endogenous regulators of the GABA(A) receptor. Nat Rev Neurosci 6:565-575.

Bogdanov Y, Michels G, Armstrong-Gold C, Haydon PG, Lindstrom J, Pangalos M, Moss SJ (2006) Synaptic GABAA receptors are directly recruited from their extrasynaptic counterparts. EMBO J 25:4381-4389.

Borowicz KK, Luszczki J, Matuszek M, Kleinrok Z, Czuczwar SJ (2002) Effects of tamoxifen, mifepristone and cyproterone on the electroconvulsive threshold and pentetrazole-induced convulsions in mice. Pol J Pharmacol 54:103-109.

Brandon NJ, Delmas P, Kittler JT, McDonald BJ, Sieghart W, Brown DA, Smart TG, Moss SJ (2000) $\mathrm{GABA}_{\mathrm{A}}$ receptor phosphorylation and functional modulation in cortical neurons by a protein kinase C-dependent pathway. J Biol Chem 275:38856-38862.

Brandon NJ, Jovanovic J, Colledge M, Coomes R, Scott J, Smart TG, Moss SJ (2001) $\mathrm{GABA}_{\mathrm{A}}$ receptor function is modulated via multiple interactions with both protein kinases and kinase anchoring proteins. J Neurochem 78:102.

Brussaard AB, Koksma JJ (2003) Conditional regulation of neurosteroid sensitivity of GABAA receptors. Ann NY Acad Sci 1007:29-36.

Brussaard AB, Wossink J, Lodder JC, Kits KS (2000) Progesteronemetabolite prevents protein kinase $\mathrm{C}$-dependent modulation of gammaaminobutyric acid type A receptors in oxytocin neurons. Proc Natl Acad Sci USA 97:3625-3630.

Chadda R, Devaud LL (2004) Sex differences in effects of mild chronic stress on seizure risk and GABAA receptors in rats. Pharmacol Biochem Behav 78:495-504.

Concas A, Mostallino MC, Porcu P, Follesa P, Barbaccia ML, Trabucchi M, Purdy RH, Grisenti P, Biggio G (1998) Role of brain allopregnanolone in the plasticity of gamma-aminobutyric acid type A receptor in rat brain during pregnancy and after delivery. Proc Natl Acad Sci USA 95:13284-13289.

Essrich C, Lorez M, Benson JA, Fritschy JM, Luscher B (1998) Postsynaptic clustering of major GABA(A) receptor subtypes requires the gamma 2 subunit and gephyrin. Nat Neurosci 1:563-571.

Fancsik A, Linn DM, Tasker JG (2000) Neurosteroid modulation of GABA IPSCs is phosphorylation dependent. J Neurosci 20:3067-3075.

Fang X, Wong S, Mitchell BF (1997) Effects of RU486 on estrogen, progesterone, oxytocin, and their receptors in the rat uterus during late gestation. Endocrinology 138:2763-2768.

Frucht MM, Quigg M, Schwaner C, Fountain NB (2000) Distribution of seizure precipitants among epilepsy syndromes. Epilepsia 41:1534-1539.

Gould E, Woolley CS, Frankfurt M, McEwen BS (1990) Gonadal-steroids regulate dendritic spine density in hippocampal pyramidal cells in adulthood. J Neurosci 10:1286-1291.

Griffiths J, Lovick T (2005a) Withdrawal from progesterone increases expression of alpha4, beta1, and delta GABA(A) receptor subunits in neurons in the periaqueductal gray matter in female Wistar rats. J Comp Neurol 486:89-97.

Griffiths JL, Lovick TA (2005b) GABAergic neurones in the rat periaqueductal grey matter express alpha4, betal and delta GABAA receptor subunits: plasticity of expression during the estrous cycle. Neuroscience 136:457-466

Harney SC, Frenguelli BG, Lambert JJ (2003) Phosphorylation influences neurosteroid modulation of synaptic GABA(A) receptors in rat CA1 and dentate gyrus neurones. Neuropharmacology 45:873-883.

Herzog AG, Frye CA (2003) Seizure exacerbation associated with inhibition of progesterone metabolism. Ann Neurol 53:390-391.

Hodge CW, Raber J, McMahon T, Walter H, Sanchez-Perez AM, Olive MF, Mehmert K, Morrow AL, Messing RO (2002) Decreased anxiety-like behavior, reduced stress hormones, and neurosteroid supersensitivity in mice lacking protein kinase C epsilon. J Clin Invest 110:1003-1010.

Kawakami M, Seto K, Yoshida K, Miyamoto T (1969) Biosynthesis of ovarian steroids in the rabbit: influence of progesterone or estradiol implantation into the hypothalamus and limbic structures. Neuroendocrinology 5:303-321.

Kittler JT, Moss SJ (2003) Modulation of GABA(A) receptor activity by phosphorylation and receptor trafficking: implications for the efficacy of synaptic inhibition. Curr Opin Neurobiol 13:341-347. 
Kokate TG, Banks MK, Magee T, Yamaguchi S, Rogawski MA (1999) Finasteride, a 5alpha-reductase inhibitor, blocks the anticonvulsant activity of progesterone in mice. J Pharmacol Exp Ther 288:679-684.

Krystal JH, Staley J, Mason G, Petrakis IL, Kaufman J, Harris RA, Gelernter J, Lappalainen J (2006) Gamma-aminobutyric acid type A receptors and alcoholism: intoxication, dependence, vulnerability, and treatment. Arch Gen Psychiatry 63:957-968.

Lauber AH, Romano GJ, Pfaff DW (1991) Gene-expression for estrogen and progesterone-receptor messenger-RNAs in rat-brain and possible relations to sexually dimorphic functions. J Steroid Biochem Mol Biol 40:53-62.

Li XT, O'Malley BW (2003) Unfolding the action of progesterone receptors. J Biol Chem 278:39261-39264.

Maguire JL, Stell BM, Rafizadeh M, Mody I (2005) Ovarian cycle-linked changes in $\mathrm{GABA}(\mathrm{A})$ receptors mediating tonic inhibition alter seizure susceptibility and anxiety. Nat Neurosci 8:797-804.

McEwen BS (2002) The neurobiology and neuroendocrinology of stress Implications for post-traumatic stress disorder from a basic science perspective. Psychiatr Clin North Am 25:469-494.

Nusser Z, Mody I (2002) Selective modulation of tonic and phasic inhibitions in dentate gyrus granule cells. J Neurophysiol 87:2624-2628.

Orchinik M, Weiland NG, McEwen BS (1995) Chronic exposure to stress levels of corticosterone alters GABAA receptor subunit mRNA levels in rat hippocampus. Brain Res Mol Brain Res 34:29-37.

Pericic D, Jazvinscak M, Svob D, Mirkovic K (2001) Swim stress alters the behavioural response of mice to GABA-related and some GABAunrelated convulsants. Epilepsy Res 43:145-152.

Pierson RC, Lyons AM, Greenfield Jr LJ (2005) Gonadal steroids regulate GABAA receptor subunit mRNA expression in NT2-N neurons. Brain Res Mol Brain Res 138:105-115.

Purdy RH, Morrow AL, Moore PH, Paul SM (1991) Stress-induced elevations of gamma-aminobutyric acid type A receptor-active steroids in the rat brain. Proc Natl Acad Sci USA 88:4553-4557.

Reddy DS (2003) Is there a physiological role for the neurosteroid THDOC in stress-sensitive conditions? Trends Pharmacol Sci 24:103-106.

Reddy DS (2006) Physiological role of adrenal deoxycorticosterone-derived neuroactive steroids in stress-sensitive conditions. Neuroscience 138:911-920.

Reddy DS, Rogawski MA (2002) Stress-induced deoxycorticosteronederived neurosteroids modulate $\mathrm{GABA}(\mathrm{A})$ receptor function and seizure susceptibility. J Neurosci 22:3795-3805.

Schwartz RD, Wess MJ, Labarca R, Skolnick P, Paul SM (1987) Acute stress enhances the activity of the GABA receptor-gated chloride-ion channel in brain. Brain Res 411:151-155.

Serra M, Pisu MG, Littera M, Papi G, Sanna E, Tuveri F, Usala L, Purdy RH, Biggio G (2000) Social isolation-induced decreases in both the abundance of neuroactive steroids and $\mathrm{GABA}(\mathrm{A})$ receptor function in rat brain. J Neurochem 75:732-740.

Shen H, Gong QH, Yuan M, Smith SS (2005) Short-term steroid treatment increases delta $\mathrm{GABA}(\mathrm{A})$ receptor subunit expression in rat CA1 hippocampus: pharmacological and behavioral effects. Neuropharmacology 49:573-586.
Simerly RB, Young BJ (1991) Regulation of estrogen receptor messenger ribonucleic acid in rat hypothalamus by sex steroid hormones. Mol Endocrinol 5:424-432.

Skerritt JH, Trisdikoon P, Johnston GA (1981) Increased GABA binding in mouse brain following acute swim stress. Brain Res 215:398-403.

Stell BM, Mody I (2002) Receptors with different affinities mediate phasic and tonic $\operatorname{GABA}(\mathrm{A})$ conductances in hippocampal neurons. J Neurosci 22:RC223(1-5).

Stell BM, Brickley SG, Tang CY, Farrant M, Mody I (2003) Neuroactive steroids reduce neuronal excitability by selectively enhancing tonic inhibition mediated by delta subunit-containing GABA(A) receptors. Proc Natl Acad Sci USA 100:14439-14444.

Steward O, Schuman EM (2001) Protein synthesis at synaptic sites on dendrites. Annu Rev Neurosci 24:299-325.

Sundstrom-Poromaa I, Smith DH, Gong QH, Sabado TN, Li XS, Light A, Wiedmann M, Williams K, Smith SS (2002) Hormonally regulated alpha(4)beta(2)delta GABA(A) receptors are a target for alcohol. Nat Neurosci 5:721-722.

Terasawa E, Timiras PS (1968) Electrical activity during the estrous cycle of the rat: cyclic changes in limbic structures. Endocrinology 83:207-216.

Teyler TJ, Vardaris RM, Lewis D, Rawitch AB (1980) Gonadal steroids: effects on excitability of hippocampal pyramidal cells. Science 209:1017-1018.

Wei WZ, Zhang NH, Peng ZC, Houser CR, Mody I (2003) Perisynaptic localization of delta subunit-containing GABA(A) receptors and their activation by GABA spillover in the mouse dentate gyrus. J Neurosci 23:10650-10661.

Wei WZ, Faria LC, Mody I (2004) Low ethanol concentrations selectively augment the tonic inhibition mediated by delta subunit-containing GABA(A) receptors in hippocampal neurons. J Neurosci 24:8379-8382.

Weiland NG, Orchinik M (1995) Specific subunit mRNAs of the GABAA receptor are regulated by progesterone in subfields of the hippocampus. Brain Res Mol Brain Res 32:271-278.

Wilson MA, Biscardi R (1997) Influence of gender and brain region on neurosteroid modulation of GABA responses in rats. Life Sci 60:1679-1691.

Woolley CS (2000) Estradiol facilitates kainic acid-induced, but not flurothyl-induced, behavioral seizure activity in adult female rats. Epilepsia 41:510-515.

Woolley CS, McEwen BS (1992) Estradiol mediates fluctuation in hippocampal synapse density during the estrous cycle in the adult rat. J Neurosci 12:2549-2554.

Woolley CS, McEwen BS (1993) Roles of estradiol and progesterone in regulation of hippocampal dendritic spine density during the estrous cycle in the rat. J Comp Neurol 336:293-306.

Woolley CS, McEwen BS (1994) Estradiol regulates hippocampal dendritic spine density via an $\mathrm{N}$-methyl-D-aspartate receptor-dependent mechanism. J Neurosci 14:7680-7687.

Xu L, Holscher C, Anwyl R, Rowan MJ (1998) Glucocorticoid receptor and protein/RNA synthesis-dependent mechanisms underlie the control of synaptic plasticity by stress. Proc Natl Acad Sci USA 95:3204-3208. 